\title{
Quantitative Microbial Risk Assessment of Pediatric Infections Attributable to Ingestion of Fecally Contaminated Domestic Soils in Low-Income Urban Maputo, Mozambique
}

\author{
Drew Capone, Aaron Bivins, Jackie Knee, Oliver Cumming, Rassul Nalá, and Joe Brown*
}

Cite This: Environ. Sci. Technol. 2021, 55, 1941-1952

Read Online

\section{ACCESS | Llll Metrics \& More | 国 Article Recommendations | (I) Supporting Information}

ABSTRACT: Rigorous studies of water, sanitation, and hygiene interventions in low- and middle-income countries (LMICs) suggest that children are exposed to enteric pathogens via multiple interacting pathways, including soil ingestion. In 30 compounds (household clusters) in low-income urban Maputo, Mozambique, we cultured Escherichia coli and quantified gene targets from soils ( E. coli: $y b b W$, Shigella/enteroinvasive E. coli (EIEC): ipaH, Giardia duodenalis: $\beta$-giardin) using droplet digital PCR at three compound locations (latrine entrance, solid waste area, dishwashing area). We found that $88 \%$ of samples were positive for culturable E. coli (mean $=3.2 \log _{10}$ CFUs per gram of dry soil), $100 \%$ for molecular E. $\operatorname{coli}$ (mean $=5.9 \log _{10}$ gene copies per gram of dry soil), $44 \%$ for

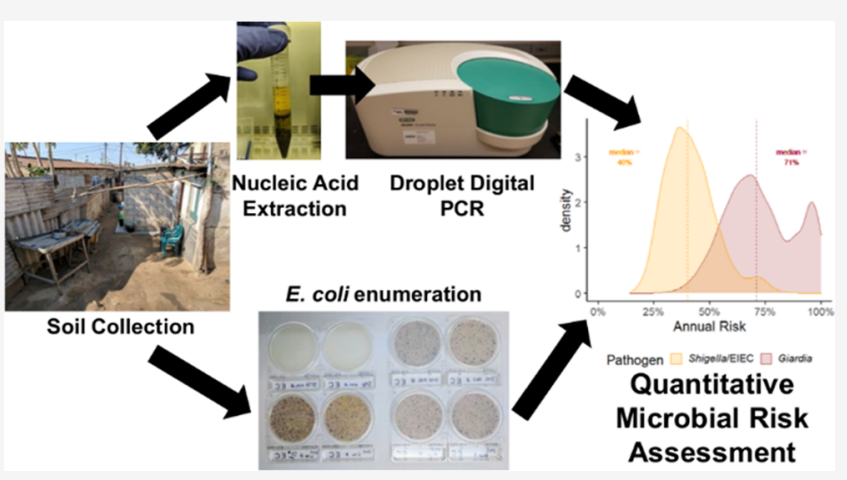
$i p a H\left(\right.$ mean $\left.=2.5 \log _{10}\right)$, and $41 \%$ for $\beta$-giardin $\left(\right.$ mean $\left.=2.1 \log _{10}\right)$.

Performing stochastic quantitative microbial risk assessment using soil ingestion parameters from an LMIC setting for children 1223 months old, we estimated that the median annual infection risk by G. duodenalis was 7100 -fold ( $71 \%$ annual infection risk) and by Shigella/EIEC was 4000 -fold (40\% annual infection risk) greater than the EPA's standard for drinking water. Compounds in Maputo, and similar settings, require contact and source control strategies to reduce the ingestion of contaminated soil and achieve acceptable levels of risk.

\section{INTRODUCTION}

In low- and middle-income countries (LMICs), children may be chronically exposed to enteric pathogens during the first years of life. ${ }^{1}$ Such exposures can lead to enteric infections, with or without diarrheal disease, ${ }^{2}$ and a range of hypothesized effects including poor growth, ${ }^{3}$ adverse cognitive development, ${ }^{4}$ negative effects on the immune system, ${ }^{5}$ and reduced efficacy of oral vaccines. ${ }^{6}$ Rigorous studies of water, sanitation, and hygiene (WASH) interventions in LMICs have reported mixed impacts on child health and that multiple inter-related environmental pathways transmit enteric pathogens from feces to new hosts in these settings. ${ }^{7-12}$ Across a diverse range of rural and urban settings in LMICs, the ingestion of fecally contaminated soils is increasingly recognized as a potentially important route of exposure. ${ }^{13-17}$ Some children may practice geophagy, ${ }^{14,16,17}$ a form of pica ${ }^{18}$ involving deliberate soil ingestion, which has been associated with environmental enteropathy, ${ }^{19}$ stunting, ${ }^{19}$ and grow-faltering. ${ }^{20,21}$ Unintentional soil ingestion may also occur directly ${ }^{15}$ or indirectly via hands, food, fomites, or household stored water. ${ }^{15}$ Estimating infection risks from soil ingestion may be useful to inform intervention strategies and reduce risks.

Fecal contamination of soils is common where safely managed sanitation or adequate animal feces management is absent. $^{22}$ Both fecal indicator bacteria (FIB) and gene targets from enteric pathogens have been detected at high densities in soils from domestic and public environments where human and animal feces lack safe management. ${ }^{23-29}$ The risk of enteric infection in these settings may be high if contact with soils is common. Soil ingestion may be an important pathway of disease transmission in specific settings, populations, and age groups. ${ }^{30}$ Quantitative microbial risk assessment (QMRA) is a systematic, mechanistic, evidence-based framework for estimating risks of microbial exposure. ${ }^{31,32}$ Combining QMRA with stochastic methods propagates the variability and uncertainty from model parameters to demonstrate the potential range of expected risks. Whereas epidemiological studies often require large sample sizes to detect differences in low-frequency outcomes, and subsequently are expensive, QMRA offers an alternative approach to estimate infection risks. As such, QMRA has often been used to characterize the

Received: October 15, 2020

Revised: January 7, 2021

Accepted: January 8, 2021

Published: January 21, 2021

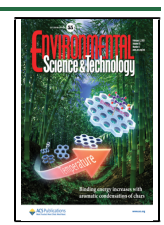


risk of activities with a low independent probability of infection, such as consumption of contaminated drinking water $^{33-35}$ or ingestion of surface water during recreational activities. $^{35-37}$

Given the increasing attention to fecally contaminated soils in the literature, some QMRA models have investigated the potential infection risks posed by soils. ${ }^{38,39}$ However, previously soil-focused QMRA models applied to LMICs have not used stochastic methods, ${ }^{38}$ assumed $100 \%$ pathogen viability, ${ }^{38}$ assumed a large amount of soil ingested per dose ${ }^{39}$ (e.g., five grams of soil), or did not include a sensitivity analysis. ${ }^{38,39}$ In addition, we know of no previous study using measured enteric infection prevalence in a concurrent cohort to assess whether the output of a QMRA model for soil ingestion was reasonable.

The data for the current QMRA were collected as part of the Maputo Sanitation (MapSan) trial, a controlled, before-andafter trial that assessed the impact of a shared onsite sanitation intervention on children's health in low-income urban Maputo, Mozambique. ${ }^{40}$ The primary outcome in the MapSan trial was the prevalence of bacterial or protozoan infection as indicated by pathogen detection in child stool samples, measured by a multiplex reverse transcription PCR assay. ${ }^{41}$ The aims of this study are to (1) use QMRA to assess the annual risk of infection by Shigella/enteroinvasive Escherichia coli (EIEC) and Giardia duodenalis from ingestion of fecally contaminated soils in the domestic environment in the MapSan trial cohort, (2) use sensitivity analyses to investigate the relationship between input parameters and estimated risks, and (3) compare model output with the age-stratified point prevalence of Shigella/ EIEC and $G$. duodenalis among children enrolled in the MapSan trial. We focused on Shigella/EIEC and G. duodenalis as these were the most prevalent bacterial and protozoan enteric pathogens identified in the MapSan trial at 24 months of follow-up; ${ }^{42}$ Shigella/EIEC was present in approximately $55 \%$ (95\% CI: 53-59\%) and G. duodenalis in 63\% (60-66\%) of stools from all children enrolled in this cohort (mean sampling age $=38$ months, $\mathrm{SD}=20$ ).

\section{METHODS}

Sample Selection. We randomly selected 15 control and 15 intervention compounds for inclusion in this study from a list of 80 MapSan trial compounds enrolled in a previous study between May and June 2018. ${ }^{26}$ The intervention consisted of a cinder block superstructure containing a pour flush toilet connected to a septic tank and a drain field, while control compounds continued using their existing shared sanitation technologies. ${ }^{40-43}$ We selected three soil sampling locations per compound representing a total of 90 samples. Sample locations included a point $25 \mathrm{~cm}$ directly in front of (1) the latrine entrance, $(2)$ the outside solid waste storage container or pile (solid waste was typically stored in a rice sack), and (3) the point in the outside area where compound members indicated that they most frequently washed dishes. Where concrete flooring was present, we sampled the nearest point not covered by concrete. We selected these standardized locations because pilot work in February 2018 revealed that children do not consistently play in any specific compound area (Text S1) and the locations represent three plausible locations where fecal contamination may be introduced in high quantities into domestic soils. Latrine entrance soils may receive an input of fecal material from latrines that inadequately sequester fecal wastes, while soils at solid waste storage areas may be contaminated from the improper disposal of children's feces or other fecally contaminated solid wastes, including animal feces. However, soils at dishwashing areas have no similar point source of fecal contamination but, instead, may receive fecal wastes from various sources or mechanisms that contribute to fecal contamination in the domestic environment (e.g., yard cleaning, walking, and wind). As the population density is high in study neighborhoods (>15000 people per square kilometer) ${ }^{44}$ we assumed that the pathogen distribution from these three locations is adequate to estimate a range of children's plausible infection risks from soil ingestion, although our estimates may represent an upper bound on infection risk given that the selected sampling locations may be more contaminated than other locations where children play.

Sample Collection. We homogenized $100 \mathrm{~cm}^{3}$ of soil using a sterilized spade and scooped soil into four cryovials at each sampling location and then transported soils on ice for $\leq 6$ $\mathrm{h}$ until the tubes were frozen at $-80^{\circ} \mathrm{C}$ or used to enumerate E. coli. Samples were shipped from the Mozambican National Institute of Health in Maputo, Mozambique, to the Georgia Institute of Technology in Atlanta, GA, on dry ice $\left(-80{ }^{\circ} \mathrm{C}\right)$ with in-transit temperature monitoring for molecular analysis.

Culturable E. coli Enumeration. We used a method modified from Boehm et al. 2009 to culture E. coli. ${ }^{45}$ First, we eluted 1 gram of soil (wet-weight) in $100 \mathrm{~mL}$ of distilled water inside a Whirl-Pak bag (Nasco, Fort Atkinson, WI). Then, we manually shook samples for $2 \mathrm{~min}$, waited $15 \mathrm{~min}$ to allow for settling, pipetted $1 \mathrm{~mL}$ of supernatant onto a Compact Dry plate (Compact Dry EC, VWR, Vienna, Austria), and incubated plates at $37^{\circ} \mathrm{C}$ for $24 \mathrm{~h}$ before counting colonyforming units (CFUs). Two biological replicates were tested from each sample, and the average of the two was used as the final E. coli count. When a sample yielded colonies too numerous to count, we retested the sample using a $1: 15$ dilution of the supernatant. Based on the manufacturer's instructions and the dilutions used, the lower limit of detection was $2 \log _{10}$ CFU E. coli per gram of soil, not accounting for moisture content, and the upper limit of detection was 6.48 $\log _{10}$ CFU E. coli per gram of soil. ${ }^{29}$

Nucleic Acid Extraction. We heated a $500 \mathrm{mg}$ aliquot of each soil sample at $105{ }^{\circ} \mathrm{C}$ for $1 \mathrm{~h}$ to determine moisture content by mass (Figure S1 and Table S1), discarded the dry soil, and then extracted nucleic acids from a separate $1 \mathrm{~g}$ portion of each sample (dry weight). Following the manufacturer's protocol, we extracted DNA using the RNeasy PowerSoil DNA Elution Kit, and RNA with the RNeasy PowerSoil Total RNA Kit (Qiagen, Hilden, Germany). We spiked samples with MS2 as a qualitative extraction control and included one negative extraction control on each day of extractions (typically 15 samples per day).

Droplet Digital PCR. We first tested for the presence of the extraction control $\mathrm{MS2}^{46}$ using reverse transcription PCR on an ABI 7500 (Applied Biosystems, Foster City, CA) and then quantified gene copies of $y b b W$ (molecular E. coli), ${ }^{47}$ ipaH (Shigella/EIEC), ${ }^{48}$ and $\beta$-giardin ( $G$. duodenalis assemblage B) ${ }^{49}$ using droplet digital PCR with a QX200 droplet reader (Bio-Rad Laboratories, Hercules, CA). Reaction conditions and thermal cycling parameters can be found in Table S2. Following the probit method proposed by Stokdyk et al. 2016, ${ }^{50}$ we assayed a dilution series of Gblocks (Integrated DNA Technologies, Coralville, IA) to determine the $95 \%$ limit of detection (LOD) of our ipa $H$ and $\beta$-giardin 


\section{Table 1. Input Parameters for QMRA Model}

\begin{tabular}{|c|c|c|}
\hline model variable & stochastic parameters used & references \\
\hline \multicolumn{3}{|c|}{ Exposure Assessment } \\
\hline \multirow{2}{*}{$\begin{array}{l}\text { nondetect values of ipaH and } \beta \text {-giardin (gene copies per } \\
\text { gram soil) }\end{array}$} & $\mathrm{U}(0,95 \% \mathrm{LOD})$ & Stokdyk et al. $2016^{50}$ \\
\hline & & Canales et al. $2018^{51}$ \\
\hline nondetect values of CFUs E. coli & $\mathrm{U}(0, \mathrm{LOD})$ & Canales et al. $2018^{51}$ \\
\hline \multirow[t]{3}{*}{ gene copies $\beta$-giardin per gram dry soil } & $\begin{array}{l}\text { LN distribution with the following LN parameter } \\
\text { distributions: }\end{array}$ & MLE, this study \\
\hline & mean $=\mathrm{LN}(1.5,0.019)$ & \\
\hline & $\mathrm{sd}=\mathrm{LN}(0.45,0.076)$ & \\
\hline \multirow[t]{3}{*}{ gene copies ipaH gene per gram dry soil } & $\begin{array}{l}\text { LN distribution with the following LN parameter } \\
\text { distributions: }\end{array}$ & MLE, this study \\
\hline & mean $=\mathrm{LN}(1.7,0.016)$ & \\
\hline & $\mathrm{sd}=\mathrm{LN}(0.41,0.078)$ & \\
\hline \multirow[t]{4}{*}{ soil ingested (grams/day) (EPA 2017) } & $\begin{array}{l}<6 \text { months: } \mathrm{LN}(-4.2,0.78)(\text { mean }=40 \mathrm{mg} / \text { day, } \mathrm{sd}=31 \mathrm{mg} / \\
\text { day) }\end{array}$ & $\begin{array}{l}\text { EPA Exposure Factors Handbook } \\
\text { Chapter } 5 \text { (2017 update })^{53}\end{array}$ \\
\hline & $\begin{array}{l}\text { 6-11 months: } \mathrm{LN}(-4.0,0.95)(\text { mean }=70 \mathrm{mg} / \text { day, } \mathrm{sd}=66 \\
\mathrm{mg} / \text { day) }\end{array}$ & \\
\hline & $\begin{array}{l}\text { 12-23 months: } \mathrm{LN}(-3.4,0.68)(\text { mean }=90 \mathrm{mg} / \text { day, } \mathrm{sd}=56 \\
\mathrm{mg} / \text { day })\end{array}$ & \\
\hline & $\begin{array}{l}\text { 24-71 months: } \operatorname{LN}(-4.0,0.95)(\text { mean }=60 \mathrm{mg} / \text { day, } \mathrm{sd}=71 \\
\text { mg/day) }\end{array}$ & \\
\hline \multirow[t]{5}{*}{ soil ingested (grams/day) (Kwong et al. 2019) } & $\begin{array}{l}\text { 3-5 months: } \mathrm{LN}(-1.8,0.69) \text { (geometric mean }=162 \mathrm{mg} / \\
\text { day, geo sd }=2)\end{array}$ & Kwong et al. $2019^{15}$ \\
\hline & $\begin{array}{l}\text { 6-11 months: } \mathrm{LN}(-1.5,0.69)(\text { geometric mean }=224 \mathrm{mg} / \\
\text { day, geo } \mathrm{sd}=2)\end{array}$ & \\
\hline & $\begin{array}{l}12-23 \text { months: } \mathrm{LN}(-1.5,0.69)(\text { geometric mean }=234 \mathrm{mg} / \\
\text { day, geo sd }=2)\end{array}$ & \\
\hline & $\begin{array}{l}\text { 24-35 months: } \mathrm{LN}(-1.8,0.69) \text { (geometric mean }=168 \mathrm{mg} / \\
\text { day, geo sd }=2)\end{array}$ & \\
\hline & $\begin{array}{l}\text { 36-47 months: } \mathrm{LN}(-1.7,0.69)(\text { geometric mean }=178 \mathrm{mg} / \\
\text { day, geo } \mathrm{sd}=2)\end{array}$ & \\
\hline $\begin{array}{l}\text { soil ingested (grams/day) for Geophagy (Geissler et al. } \\
\text { 1997) }\end{array}$ & $\begin{array}{l}12-71 \text { months: } \operatorname{Tri}(8,28,108)(\text { minimum }=8 \mathrm{~g} / \text { day, } \text { mode }= \\
28 \mathrm{~g} / \text { day, } \text { maximum }=108 \mathrm{~g} / \text { day })\end{array}$ & Geissler et al. $1997^{17}$ \\
\hline $\begin{array}{l}\text { culturable E. coli in intracompound soils }\left(\log _{10} \mathrm{CFU} /\right. \\
\text { gram of dry soil) }\end{array}$ & $\mathrm{N}(3.2,1.1)$ & this study \\
\hline $\begin{array}{l}y b b W \text { in intracompound soils ( } \log _{10} \text { gene copies/gram of } \\
\text { dry soil) }\end{array}$ & $\mathrm{N}(5.9,0.36)$ & this study \\
\hline \multirow{2}{*}{$\begin{array}{l}\text { ratio of viable Shigella/EIEC CFUs: Proportion of } \\
\text { culturable E. coli to molecular } y b b W \text { GC }\end{array}$} & $\mathrm{LN}(-6.2,2.4)$ & MLE, this study \\
\hline & $\begin{array}{l}\text { LN distribution from ratios of CFUs E. coli to } y b b W \\
\text { (truncated at } 1 \text { ) }\end{array}$ & \\
\hline \multirow[t]{2}{*}{ ratio of viable Giardia cysts } & $\mathrm{LN}(-6.2,2.4)$ & MLE, this study \\
\hline & $\begin{array}{l}\mathrm{LN} \text { distribution from ratios of CFUs E. coli to } y b b W \\
\text { (truncated at 1) }\end{array}$ & \\
\hline$\beta$-giardin gene copies per cyst & 16 & Bernander et al. $2001^{55}$ \\
\hline ipaH gene copies per $\mathrm{CFU}$ & $\mathrm{U}(5,14)$ & Lin et al. $2010^{48}$ \\
\hline \multirow[t]{2}{*}{$y b b W$ gene copies per $E$. coli genome } & 1 & Walker et al. $2017^{47}$ \\
\hline & Dose-Response & \\
\hline G. duodenalis dose-response parameter, $k$ & $\mathrm{LN}(0.0208,0.0064)$ & Rose et al. $1991^{58}$ \\
\hline \multirow[t]{2}{*}{ Shigella/EIEC dose-response parameters, $\alpha, \mathrm{N}_{50}$} & $\log \alpha \mathrm{N}(-0.5768,0.0961)$ & Dupont et al. $1972^{56}$ \\
\hline & $\log \mathrm{N}_{50} \mathrm{~N}(3.170,0.1397)$ & Crockett et al. $1996^{57}$ \\
\hline
\end{tabular}

${ }^{a}$ Note: $\mathrm{LN}=\log$-normal (mean, sd); $\mathrm{N}=$ normal (mean, sd); $\mathrm{U}=$ uniform (min, max); and Tri = triangle (min, mode, max). Values correspond to the inputs used for the rlnorm, rnorm, rtri functions in $\mathrm{R}$.

assays in triplicate (Figure S2). Manual thresholding was performed between positive and negative clusters taking into account the observed clusters in positive controls and extraction blanks to classify positive droplets (Figures S3 and S4).

Exposure Assessment. To model the distribution of ipaH and $\beta$-giardin in soils, we used an imputation method in combination with maximum-likelihood estimation to estimate distribution parameters. ${ }^{51}$ Briefly, from our complete data set of detects and nondetects, we imputed values for each nondetection observed by drawing from a uniform distribution from zero to the 95\% LOD (ipaH: 315 gene copies per gram dry soil; $\beta$-giardin: 100 gene copies per gram dry soil). We repeated this process 100 times to create 100 unique data sets. Then, we used the fitdistrplus ${ }^{52}$ package in $\mathrm{R}$ ( $\mathrm{R}$ version 4.0.0, $\mathrm{R}$ Foundation for Statistical Computing, Vienna, Austria) to fit a log-normal distribution to the mean and standard deviation (SD) parameters from the 100 imputed data sets. As such, the final models were log-normal distributions for the density of ipa $H$ and $\beta$-giardin genes in domestic soils where the mean and standard deviation were themselves log-normal distributions.

Without site-specific soil ingestion data, we developed QMRA models based on two plausible soil ingestion scenarios. First, we used parameters from the U.S. EPA Exposure Factors 
Handbook Chapter 5 (2017 update), ${ }^{53}$ which are derived from tracer studies, biokinetic models, and activity pattern models. These daily estimates represent a low ingestion scenario from children living in a high-income country. Children in highincome countries may spend less time outside than in lowincome countries, ${ }^{54}$ and their exposures may be reduced by improved flooring, the presence of vegetation or solid surfaces in outdoor spaces, and better sanitation limiting fecal contamination of the environment in general. These factors suggest that the EPA soil ingestion estimates may be conservative for settings in low-income countries where outside play and contact with soil may be more prevalent. Second, to represent a high ingestion scenario, we used parameters from Kwong et al. 2019, a study that included direct observation of children in rural Bangladesh (Table 1). Similar to that study, the outdoor space in compounds in urban Maputo is often dirt with few areas covered by concrete or vegetation (Figure S5). Recognizing that children's interaction with their environment likely changes with age, we disaggregate our exposure assessments and risk estimates by age based on the available ingestion estimates from our two sources (Table 1). In addition, evidence suggests that some children practice geophagy, ${ }^{14,16}$ which is the intentional ingestion of soils. Accordingly, we include soil ingestion estimates for such children from Geissler et al. $1997 .^{17}$

Dose Harmonization and Infectious Unit. Shigella/ EIEC CFUs and G. duodenalis cysts contain multiple copies of our target sequences. To account for this in our models, we included a uniform distribution (5-14 gene copies ipaH/ $\mathrm{CFU})^{48}$ for Shigella/EIEC and a static input (16 gene copies $\beta$ giardin/cyst) ${ }^{55}$ for G. duodenalis (Table 1).

To estimate the proportion of viable Shigella/EIEC colonyforming units (CFUs) and G. duodenalis cysts, we divided each soil sample's count of $E$. coli CFUs by its matched density of $y b b W$ gene copies (Table 1). ${ }^{47}$ Then, we used maximumlikelihood estimation (MLE) (fitdistrplus package in $\mathrm{R})^{52}$ to fit a log-normal distribution to these ratios to use as an input for the viable proportion in our QMRA model (Table 1).

Dose-Response. We estimated the probability of infection with Shigella/EIEC using the approximate $\beta$-Poisson model with the $\log$ of parameters $\alpha$ and the median infectious dose normally distributed (Table 1 and Text S3). ${ }^{56,57}$ Likewise, we estimated the probability of infection with $G$. duodenalis using an exponential model with parameter $k$ log-normally distributed (Table 1 and Text S3). ${ }^{58}$

Risk Characterization. To propagate uncertainty and variability from stochastic input distributions into risk estimates, we programmed the model as a Monte Carlo simulation in $\mathrm{R}$ version 4.0.0, in which we randomly sampled from each stochastic distribution in independent trials and then calculated the daily risk of infection for each draw (Text S3). We executed the model by running 10000 independent trials. To calculate an annual probability of a single infection, we subsampled 365 daily probabilities from the 10000 generated by the model without replacement and calculated the annual probability of infection using eq $1 .^{59}$ We bootstrapped the model by repeating this process 10000 times, which we used to calculate summary statistics. To ensure reproducibility, we standardized all Monte Carlo simulations in $\mathrm{R}$ with an initial seed value of 31 .

$$
P_{\text {inf,annual }}=1-\prod_{1}^{n}\left(1-P_{\text {inf, daily, } i}\right), n=365
$$

Sensitivity Analysis. We conducted two unique analyses to assess the sensitivity of our model with stochastic input parameters for children 12-23 months old, focusing on this single age range to avoid repetition as inputs were similar. First, we ran our stochastic model while holding individual parameters constant to examine the impact on annual infection risk. ${ }^{60}$ Then, we simulated an intervention by reducing the ingested dose in increments of $1 \log _{10}$ to determine what reduction in dose, whether by contact or source control, would be necessary to achieve the EPA standard for drinking water (i.e., $\leq 1$ in 10000 annual infection risk). ${ }^{61}$

\section{RESULTS}

Fecal Contamination of Soils. We found evidence of widespread fecal contamination across all three compound sampling locations when combining the data from both trial arms (Figure 1 and Table S3). We detected the $\beta$-giardin gene

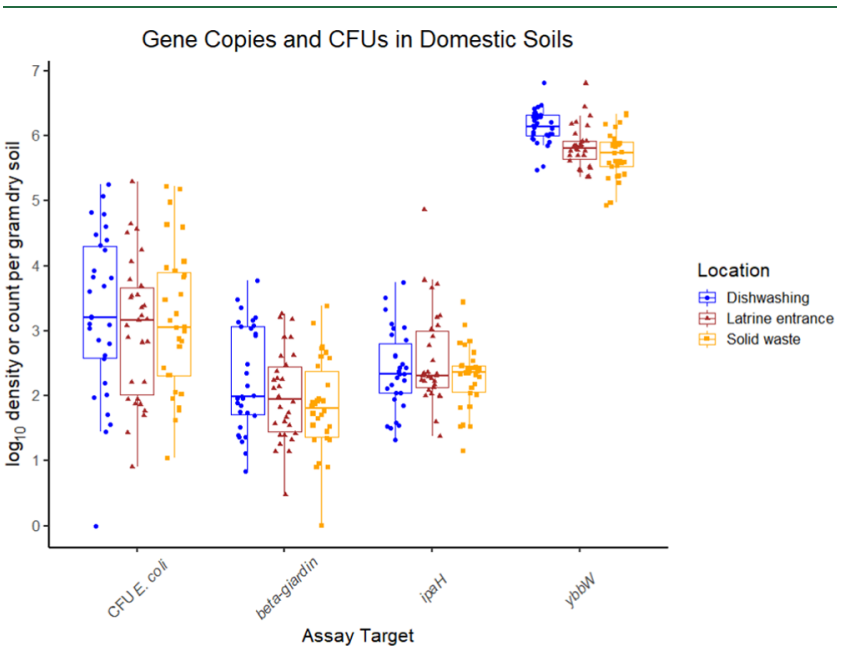

Figure 1. Results from molecular- and culture-based assays. All nondetects (NDs) were imputed to a random value from zero to the 95\% LOD for molecular assays and from zero to the LOD for the culture-based assay.

in $41 \%(37 / 90)$ of samples, the ipaH gene in $44 \%(40 / 90)$ of samples, the $y b b W$ gene in $100 \%$ of samples (90/90), and culturable E. coli in $88 \%(79 / 90)$ of samples. Per gram of dry soil, observed densities of the $\beta$-giardin gene (mean $=2.1 \log _{10}$, $\mathrm{sd}=0.61)$ and the $i p a H$ gene $\left(\right.$ mean $=2.5 \log _{10}$, sd $\left.=0.52\right)$ were relatively stable across compound locations and were substantially lower than the $y b b W$ gene $\left(\right.$ mean $=5.9 \log _{10}$, $\mathrm{sd}=$ 0.37 ). Though we more frequently detected ipaH, $\beta$-giardin, and culturable E. coli at MapSan intervention compounds compared to those at controls, the mean gene copy and CFU densities were similar (Tables S4 and S5). Results from control experiments can be found in Table S6 and ddPCR droplet counts in Table S7.

QMRA Model Output. Daily Risk. For both pathogens under both ingestion scenarios, the daily risk of infection was relatively low but was about three- to fivefold lower for the low ingestion scenario (Table S8). For example, using soil ingestion estimates from the U.S. EPA 2017, we estimated that the median daily risk of infection for a child 12-23 months old by G. duodenalis was 1 in 48000 and by Shigella/ 
EIEC was 1 in 110000 . Using soil ingestion estimates from Kwong et al. 2019, we estimated that the median daily risk of infection for a child 12-23 months old by G. duodenalis was 1 in 16000 and by Shigella/EIEC was 1 in 36000 .

Annual Risk. Regardless of age or soil ingestion scenario, we estimated that the 10th, 50th, and 90th percentiles of the annual risk of infection for both G. duodenalis and Shigella/ EIEC substantially exceeded the U.S. Environmental Protection Agency's (EPA) normative standard for drinking water ( $\leq 1$ in 10000 infection risk per year). For children 12-23 months old, using ingestion estimates from Kwong et al. 2019, the median annual risk of infection by $G$. duodenalis was $7100-$ fold and by Shigella/EIEC was 4000 -fold greater than the EPA's standard for drinking water (Table 2). As expected, because the mean amount of soil ingested was greater, the estimated annual risks were much higher using soil ingestion estimates from Kwong et al. 2019 compared to those of the U.S. EPA Exposure Factors Handbook (Figure 2A,B). Likewise, children practicing geophagy had the highest estimated annual risks (Table 2).

Sensitivity Analysis. To evaluate the impact of variation in individual parameters on the annual infection risk, we ran our model for children 12-23 months old using the Kwong et al. 2019 soil ingestion rate but fixed individual parameters to plausible values (Table 3). For both Shigella/EIEC and G. duodenalis, a 10-fold increase in the soil ingestion, gene copy density, or cyst/CFU viability parameters dramatically increased annual infection risks (Figure S6), whereas each 2fold increase in the dose-response parameter $k$ ( $G$. duodenalis) and $N_{50}$ (Shigella/EIEC) modestly increased annual infection risks.

Finally, we simulated an intervention that reduced the ingested dose $($ dose $=$ mass soil ingested per day $\times$ gene copy density per gram) in increments of $1 \log _{10}$. To achieve a median annual infection risk of $\leq 1$ in 10000 , we estimated that a $5 \log _{10}$ reduction in dose would be necessary for $G$. duodenalis and a $4 \log _{10}$ reduction for Shigella/EIEC (Figure S7 and Table S9).

\section{DISCUSSION}

We found evidence of widespread pathogen-associated genes and culturable E. coli in compound soils in low-income urban neighborhoods of Maputo, Mozambique. Regardless of the soil ingestion scenario used, the infection risks from children's ingestion of domestic soils contaminated by G. duodenalis and Shigella/EIEC were high compared with normative tolerable risk levels associated with drinking water exposures. ${ }^{61}$ Estimated annual infection risks were lowest using ingestion parameters from a high-income setting (U.S. EPA 2017), higher using ingestion parameters from a low-income setting (Kwong et al. 2019), and highest for children practicing geophagy. In both ingestion scenarios, infection risk increased with age, peaked for children 12-23 months old, and then decreased. We estimated lower infection risks using soil ingestion parameters from the U.S. EPA 2017 compared to those of Kwong et al. 2019 but simulated at least a $4 \log _{10}$ reduction in dose that was necessary to reduce risks below EPA standards for acceptable risk in drinking water. These findings suggest that both contact control (e.g., safe child play spaces or upgrading dirt floors to concrete) ${ }^{62}$ and source control (e.g., reduction of open defecation, improved latrines, improved hygienic pit emptying, animal control) ${ }^{43}$ may be useful to reduce the risk of infection by G. duodenalis and Shigella/EIEC.
Table 2. Estimated Annual Infection Risks

\begin{tabular}{|c|c|c|c|c|c|}
\hline & \multirow{2}{*}{\multicolumn{4}{|c|}{$\begin{array}{l}\text { Model output using soil ingestion estim } \\
\text { Exposure Factors Han } \\
\text { estimated annual risk of } G \text {. duodenalis } \\
\text { infection }\end{array}$}} & \multirow[b]{3}{*}{$\begin{array}{c}\text { MapSan } \\
\text { point prevalence }\end{array}$} \\
\hline & & & & & \\
\hline & percentile & $\begin{array}{l}10 \text { th } \\
(\%)\end{array}$ & $\begin{array}{c}50 \text { th } \\
(\%)\end{array}$ & $\begin{array}{c}90 \text { th } \\
(\%)\end{array}$ & \\
\hline \multirow[t]{5}{*}{ age } & $<6$ months & 9.6 & 15 & 29 & 13 \\
\hline & $6-11$ months & 16 & 26 & 54 & 22 \\
\hline & $\begin{array}{l}12-23 \\
\text { months }\end{array}$ & 20 & 31 & 48 & 59 \\
\hline & $\begin{array}{l}24-71 \\
\text { months }\end{array}$ & 13 & 21 & 38 & 73 \\
\hline & $\begin{array}{l}\text { estimated annu } \\
\text { infection }\end{array}$ & risk o & igella/1 & & $\underline{\text { point prevalence }}$ \\
\hline \multirow[t]{6}{*}{ age } & $<6$ months & 4.4 & 7.3 & 14 & 5.0 \\
\hline & $6-11$ months & 7.2 & 12 & 20 & 21 \\
\hline & $\begin{array}{l}12-23 \\
\text { months }\end{array}$ & 9.4 & 15 & 25 & 36 \\
\hline & $\begin{array}{l}24-71 \\
\text { months }\end{array}$ & 5.9 & 10 & 19 & 68 \\
\hline & \multicolumn{4}{|c|}{$\begin{array}{l}\text { Model output using soil ingestion estima } \\
\text { estimated } \frac{\text { annual risk of } G . \text { duodenalis }}{\text { infection }}\end{array}$} & Kwong et al. 2019 \\
\hline & percentile & $\begin{array}{l}10 \text { th } \\
(\%)\end{array}$ & $\begin{array}{c}50 \text { th } \\
(\%)\end{array}$ & $\begin{array}{l}90 \text { th } \\
(\%)\end{array}$ & $\begin{array}{c}\text { MapSan } \\
\text { point prevalence }\end{array}$ \\
\hline \multirow[t]{6}{*}{ age } & $3-5$ months & 39 & 57 & 83 & 13 \\
\hline & $6-11$ months & 50 & 69 & 90 & 22 \\
\hline & $\begin{array}{l}12-23 \\
\text { months }\end{array}$ & 53 & 71 & 96 & 59 \\
\hline & $\begin{array}{l}24-35 \\
\text { months }\end{array}$ & 40 & 57 & 80 & 72 \\
\hline & $\begin{array}{l}36-47 \\
\text { months }\end{array}$ & 43 & 62 & 83 & 75 \\
\hline & \multicolumn{4}{|c|}{$\begin{array}{l}\text { estimated annual risk of Shigella/EIEC } \\
\text { infection }\end{array}$} & $\underline{\text { point prevalence }}$ \\
\hline \multirow[t]{5}{*}{ age } & $3-5$ months & 19 & 29 & 45 & 5.0 \\
\hline & $6-11$ months & 25 & 36 & 51 & 21 \\
\hline & $\begin{array}{l}12-23 \\
\text { months }\end{array}$ & 28 & 40 & 56 & 36 \\
\hline & $\begin{array}{l}24-35 \\
\text { months }\end{array}$ & 21 & 31 & 47 & 56 \\
\hline & $\begin{array}{l}36-47 \\
\text { months }\end{array}$ & 21 & 32 & 47 & 73 \\
\hline & \multicolumn{5}{|c|}{$\begin{array}{l}\text { Model output using geophagy estimates from Geisler et al. } 1997 \\
\text { estimated annual risk of G. duodenalis infection }\end{array}$} \\
\hline & percentile & 10 th & & h (\%) & 90th (\%) \\
\hline & geophagy & & & $>99$ & $>99$ \\
\hline \multicolumn{6}{|c|}{ estimated annual risk of Shigella/EIEC infection } \\
\hline & geophagy & $>9$ & & $>99$ & $>99$ \\
\hline
\end{tabular}

${ }^{a}$ Note: MapSan point prevalence data represents a total of 922 children enrolled in the MapSan trial. Annual risk is for a single infection.

Such contact control strategies could be deployed rapidly but are likely insufficient, whereas improvements to source control could be more effective but would probably occur incrementally.

E. coli counts in soils were, on average, $1.6 \log _{10}$ greater than a study in urban Harare, Zimbabwe, ${ }^{29} 1.1 \log _{10}$ greater than a study in peri-urban Tanzania, ${ }^{63}$ and $2.2 \log _{10}$ less than a study in rural Bangladesh. ${ }^{64}$ Possibly due to local variations in infection prevalence or because we used ddPCR, which is less prone to inhibition than $\mathrm{qPCR},{ }^{65}$ we detected genes associated with Shigella/EIEC and Giardia more often than studies in 
A

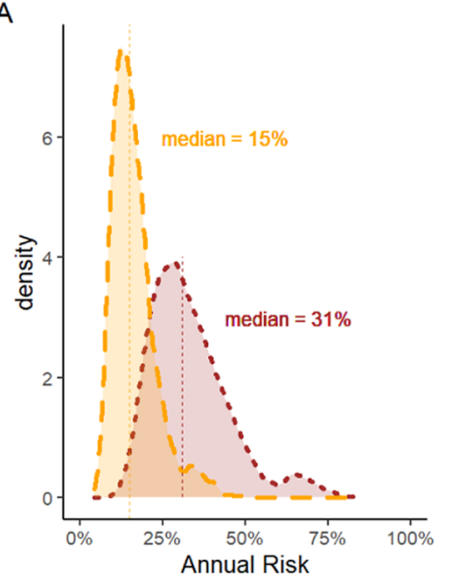

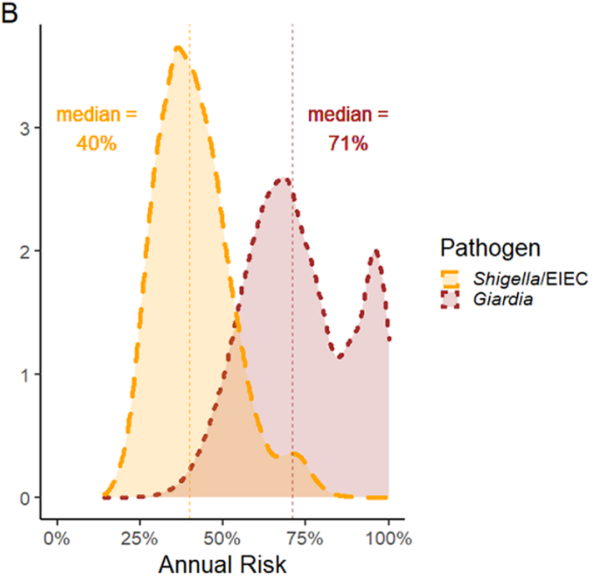

Figure 2. (A) Kernel density plot of the estimated annual risk of a single infection using ingestion parameters from Kwong et al. 2019 for children 12-23 months old. (B) Kernel density plot of the estimated annual risk of infection using ingestion parameters from Kwong et al. 2019 for children 12-23 months old.

Table 3. Sensitivity Analysis

\begin{tabular}{|c|c|c|c|c|c|c|}
\hline \multirow[b]{2}{*}{ pathogen } & \multirow[b]{2}{*}{ fixed parameter } & \multirow[b]{2}{*}{ fixed Value } & \multirow[b]{2}{*}{ units } & \multicolumn{3}{|c|}{ estimated annual risk (percentile) } \\
\hline & & & & 10th (\%) & 50th (\%) & 90th (\%) \\
\hline \multirow[t]{13}{*}{ G. duodenalis } & soil ingestion & 10 & $\mathrm{mg} /$ day & 2.7 & 4.4 & 8.1 \\
\hline & & 100 & & 24 & 36 & 57 \\
\hline & & 1000 & & 93 & 99 & $>99$ \\
\hline & gene copy density & 10 & gene copies/gram soil & 2.6 & 3.7 & 5.3 \\
\hline & & 100 & & 23 & 32 & 43 \\
\hline & & 1000 & & 92 & 98 & $>99$ \\
\hline & viability & $0.01 \%$ & $\%$ viable cysts & 0.51 & 0.65 & 0.92 \\
\hline & & $0.10 \%$ & & 5.0 & 6.4 & 8.8 \\
\hline & & $1 \%$ & & 40 & 48 & 60 \\
\hline & & $10 \%$ & & $>99$ & $>99$ & $>99$ \\
\hline & dose-response parameter $k$ & 0.00995 & unitless & 31 & 46 & 78 \\
\hline & & 0.0199 & & 53 & 71 & 95 \\
\hline & & 0.0398 & & 78 & 92 & $>99$ \\
\hline \multirow[t]{13}{*}{ Shigella/EIEC } & soil ingestion & 10 & $\mathrm{mg} /$ day & 1.2 & 1.9 & 3.3 \\
\hline & & 100 & & 11 & 17 & 27 \\
\hline & & 1000 & & 65 & 78 & 88 \\
\hline & gene copy density & 10 & gene copies/gram soil & 0.60 & 0.89 & 1.3 \\
\hline & & 100 & & 5.8 & 8.4 & 12 \\
\hline & & 1000 & & 43 & 55 & 66 \\
\hline & viability & $0.01 \%$ & $\%$ viable CFUs & 0.22 & 0.29 & 0.43 \\
\hline & & $0.10 \%$ & & 2.2 & 2.8 & 4.1 \\
\hline & & $1 \%$ & & 20 & 24 & 32 \\
\hline & & $10 \%$ & & 87 & 91 & 95 \\
\hline & dose-response parameter $N_{50}$ & 740 & CFUs & 42 & 56 & 72 \\
\hline & & 1480 & & 25 & 35 & 50 \\
\hline & & 2960 & & 13 & 20 & 31 \\
\hline
\end{tabular}

${ }^{a}$ Results from sensitivity analysis that held individual parameters constant as part of the stochastic QMRA model.

rural Bangladesh ${ }^{66}$ (Shigella/EIEC: $1.2 \%$; Giardia: $\left.<1 \%\right)$ and in urban Kenya $^{23}$ (Shigella/EIEC: <1\%; Giardia: 18\%). The presence and density of enteric pathogens and FIB are likely to be highly variable because soil contamination with fecal material is a function of sanitation infrastructure and function, the prevalence and density of various domestic animals, waste disposal practices, drainage, and other localized and contextspecific hygiene behaviors and practices. The survival of enteric pathogens in domestic soils may be related to a range of environmental factors including temperature, ${ }^{67}$ soil moisture content, $^{68,69}$ soil composition, ${ }^{67}$ and exposure to sunlight. ${ }^{70}$
Various factors may contribute to the widespread fecal contamination detected in soil. Most neighborhoods in this setting, have a population density greater than 15000 people per square kilometer and subsequently produce large amounts of human feces in a small geographic area. ${ }^{44}$ Open defecation by young children and the unsafe disposal of children's feces are common. ${ }^{41}$ Furthermore, pit latrines and septic tanks are often emptied unhygienically using manual equipment and the fecal wastes buried onsite. ${ }^{43}$ Animals are also commonly owned including cats, dogs, chickens, and ducks. ${ }^{26,41}$ We tested for $G$. duodenalis assemblage B, which can infect dogs and 
humans. ${ }^{71,72}$ In addition, it is common for people to sweep the soil surface in the shared compound living space each morning, which may help spread pathogens across domestic soils in this setting. ${ }^{73}$ Although the study's small sample size and crosssectional nature suggest a need for cautious interpretation, these factors may explain why we did not observe a drastic difference in pathogen gene copy density between MapSan intervention compounds, which were recipients of a source control intervention, ${ }^{40-43}$ and control compounds.

The dose of pathogens ingested is a product of the viable pathogen concentration estimate and the assumed quantity of soil ingested. This mathematical relationship offers two potential risk reduction strategies: source control to lower pathogen concentration and/or contact control to lower the quantity of soil ingested. Our sensitivity analysis indicated that both strategies may be effective at reducing infection risks. In addition, the median infectious dose of Shigella/EIEC $\left(\mathrm{N}_{50}=\right.$ $1480 \mathrm{CFU})^{56,57}$ is 42 times greater than G. duodenalis $\left(\mathrm{N}_{50}=\right.$ 35 cysts), ${ }^{58}$ but the observed concentrations of both pathogens were generally equivalent to tens or hundreds of pathogens per gram soil. Considering G. duodenalis assemblage B is zoonotic $^{71,72}$ and has a low median infectious dose, a comprehensive intervention targeting the source control of human and animal feces ${ }^{74,75}$ may be necessary to reduce infection risks in low-income Maputo. Unlike G. duodenalis, Shigella/EIEC is human-specific ${ }^{76}$ and therefore does not require the control of animal feces to reduce infection risk. Where source control is impracticable, as it may be with respect to zoonotic pathogens associated with waste from freeranging animals, contact control may be preferred. Hardscape, cleanable paving has been suggested as a potentially transformative intervention to reduce children's contact with contaminated soils in the domestic environment. ${ }^{62}$ Such improvements can and should be studied further to assess whether they may effectively limit exposures, especially because such interventions could also exacerbate flooding ${ }^{77}$ and the associated spread of fecal pathogens through the environment. $^{78}$

At a national policy level in LMICs, efforts to control sources and limit contact with soils would likely fall under different ministries or agencies, call on different sources of funding, and involve different actors. These differences suggest that interventions in LMICs may target source control or contact control individually. When comprehensive interventions are not possible, efforts targeting either source or contact control are necessary to progress toward the drastic reduction in dose, which our model indicates is needed to achieve acceptable levels of risk. Although rigorous trials of sanitation infrastructure found that effective source control may be a distant prospect in LMICs, ${ }^{7-12,42}$ contact control, while insufficient, may be important in the near-term to reduce infection risks.

In the QMRA literature, ingestion of soil has received less attention than other fecal-oral pathways such as water and food (Figure S8). ${ }^{79}$ Comparing our estimates of infection risk with the observed prevalence of G. duodenalis and Shigella/ EIEC infections suggests that soil ingestion alone could plausibly comprise a substantial proportion of pathogen transmission in this setting, and therefore, soils may be an understudied and underappreciated pathway in similar environments.

Though this study expands upon previous QMRA models that focused on soil ingestion, ${ }^{38,39}$ there remain numerous areas of future work to improve risk estimates. We used a ratio of culturable E. coli as CFUs to gene copies to estimate viability of specific enteric pathogens, but our sensitivity analysis indicated that a 10 -fold increase in viability would substantially increase the estimated risk. On the one hand, E. coli and other microbes may be viable but nonculturable, ${ }^{80}$ suggesting that our model underestimates risk. On the other hand, if infectivity is quickly lost and pathogen DNA are persistent, ${ }^{81}$ then our model may overestimate risk. Pretreatment with DNA-binding propidium monoazide before quantitative PCR may help improve viability estimates. ${ }^{82,83}$ Further, given the limitations of QMRA $^{32}$ and the importance of the local context, ${ }^{2}$ more research is needed to more accurately characterize soil ingestion, the subsequent infection risks, and the reduction in exposure associated with source and contact control in this setting. In addition, the dose-response models we used are derived from studies of adults in the United States. ${ }^{84}$ Their applicability to young children in an LMIC is not clear due to differences in age, lifestyle, and genetics and because repeated infections may compromise the immune system resulting in greater susceptibility to infection, or conversely, acquired immunity due to endemic exposure. ${ }^{76,85}$ Likewise, the doseresponse curve for G. duodenalis and Shigella/EIEC from soil ingestion may be different from that observed in feeding studies where participants received G. duodenalis cysts in gelatin capsules or Shigella spp. CFUs in milk. ${ }^{56,86-88}$ While we treated these input parameters as stochastic distributions to propagate this uncertainty, additional work is needed to better characterize the dose-response relationship for children in LMICs where the burden of enteric disease is high.

Our analysis is constrained by several important limitations. First, we did not collect site-specific ingestion data, but instead relied on parameters from two plausible soil ingestion rate scenarios. For these two scenarios, we extrapolated daily soil ingestion to estimate the annual risk, but the soil ingestion values may not be representative of long-term averages. ${ }^{33}$ This extrapolation may overestimate the risk for children who consistently ingest small amounts of soil or conversely underestimate the risk for children who consistently ingest relatively large amounts of soil. Second, several of our assumptions may result in overestimates of risk. Our analysis was limited to samples collected from three compound locations, which may have been more contaminated than other compound locations. Additionally, bacteria are capable of regrowth and E. coli may not be a reliable indicator of fecal contamination generally in soil. ${ }^{89,90}$ As such, it is possible that some of the $E$. coli we detected did not originate from feces but was instead part of the naturalized microbial community present in soils. If so, our model could overestimate viability of Giardia and therefore infection risks. Third, other assumptions may result in underestimates of risk. We assumed 100\% recovery efficiency of nucleic acid from our extractions, which suggests that the gene copy densities used in our model may be underestimates. As well, we tested for G. duodenalis assemblage $\mathrm{B}$, but assemblage $\mathrm{A}$ is also infectious to humans ${ }^{49}$ and subsequently our approach may underestimate the infection risks posed by $G$. duodenalis. Finally, we used a ratio of culturable E. coli to gene copies of $E$. coli to estimate $G$. duodenalis cyst and Shigella/EIEC CFU viability. Limited data suggests that the persistence of Shigella/EIEC ${ }^{91}$ in soil may be comparable to that of E. coli, but $G$. duodenalis cysts may be more persistent in the environment than E. coli. ${ }^{67,92,93}$ This may suggest that the proportion of viable $G$. duodenalis we used 
could underestimate cyst viability. In fact, given the model's strong sensitivity to the viability parameter, an underestimate of cyst viability would have resulted in an underestimation of $G$. duodenalis infection risks.

In LMICs where the relationship between sanitation and health is complex, we offer evidence that children's ingestion of fecally contaminated soils results in a high risk of infection with G. duodenalis and Shigella/EIEC. Interventions targeting contact control and source control are needed to reduce children's ingestion of fecally contaminated soils. Similar stochastic QMRA models that use objective measures of enteric pathogen gene targets from the environment in LMICs may offer improved insight into local infection risks and could inform locally relevant control strategies, including for the wide range of other important sanitation-related pathogens whose prevalence and priority for intervention vary across settings.

\section{ASSOCIATED CONTENT}

\section{SI Supporting Information}

The Supporting Information is available free of charge at https://pubs.acs.org/doi/10.1021/acs.est.0c06972.

Soil sampling location selection (Text S1); supplemental notes on ddPCR (Text S2); dose-response (Text S3); harmonization and viability soil moisture content (Figure S1); 95\% LOD determination (Figure S2); example of manual thresholding (Figure S3); example of ddPCR results (Figure S4); photos of compounds in urban Maputo, Mozambique (Figure S5); sensitivity analysis graphs (Figure S6); simulated dose reduction intervention graphs (Figure S7); results from Web of Science search (Figure S8); results from soil drying experiments (Table S1); descriptions of molecular assays (Table S2); summary of molecular- and culture-based assays from combined trial arms (Table S3); summary of molecular- and culture-based assay from 15 MapSan intervention compounds (Table S4); summary of molecular- and culture-based assays from 15 MapSan control compounds (Table S5); control experiment results (Table S6); droplet data (Table S7); estimated daily risk of infection (Table S8); and simulated dose reduction intervention (Table S9) (PDF)

\section{AUTHOR INFORMATION}

\section{Corresponding Author}

Joe Brown - Civil and Environmental Engineering, Georgia Institute of Technology, Atlanta, Georgia 30332, United States; Department of Environmental Sciences and Engineering, Gillings School of Public Health, University of North Carolina at Chapel Hill, Chapel Hill, North Carolina 27599, United States; 10 orcid.org/0000-0002-5200-4148; Email: joebrown@unc.edu; Fax: +1 919-360-8752

\section{Authors}

Drew Capone - Civil and Environmental Engineering, Georgia Institute of Technology, Atlanta, Georgia 30332, United States; Department of Environmental Sciences and Engineering, Gillings School of Public Health, University of North Carolina at Chapel Hill, Chapel Hill, North Carolina 27599, United States

Aaron Bivins - Department of Civil and Environmental Engineering and Earth Sciences, University of Notre Dame,
Notre Dame, Indiana 46556, United States; 10 orcid.org/ 0000-0001-9385-2138

Jackie Knee - Department of Disease Control, London School of Hygiene and Tropical Medicine, London WC1E 7HT, U.K.; ○ orcid.org/0000-0002-0834-8488

Oliver Cumming - Department of Disease Control, London School of Hygiene and Tropical Medicine, London WC1E 7HT, U.K.

Rassul Nalá - Ministério da Saúde, Instituto Nacional de Saúde Maputo, Maputo 1100, Mozambique

Complete contact information is available at:

https://pubs.acs.org/10.1021/acs.est.0c06972

\section{Notes}

The authors declare no competing financial interest.

\section{ACKNOWLEDGMENTS}

This study was funded by the United States Agency for International Development (www.usaid.gov) under Translating Research into Action (Cooperative Agreement No. GHS-A-00-09-00015-00) and the Bill and Melinda Gates Foundation (www.gatesfoundation.org) grant OPP1137224. The funders had no role in study design, data collection and analysis, decision to publish, or preparation of the manuscript.

\section{REFERENCES}

(1) MAL-ED Network Investigators. The MAL-ED Study: A Multinational and Multidisciplinary Approach to Understand the Relationship between Enteric Pathogens, Malnutrition, Gut Physiology, Physical Growth, Cognitive Development, and Immune Responses in Infants and Children up to 2 Years Of. Clin. Infect. Dis. 2014, 59, S193-206.

(2) Kotloff, K. L.; Nataro, J. P.; Blackwelder, W. C.; Robins-Browne, R. M.; Levine, M. M.; et al. Burden and Aetiology of Diarrhoeal Disease in Infants and Young Children in Developing Countries (the Global Enteric Multicenter Study, GEMS): A Prospective, CaseControl Study. Lancet 2013, 382, 209-222.

(3) Rogawski, E. T.; Liu, J.; Platts-Mills, J. A.; Kabir, F.; Lertsethtakarn, P.; Siguas, M.; Khan, S. S.; Praharaj, I.; Murei, A.; Nshama, R.; Mujaga, B.; Havt, A.; Maciel, I. A.; Operario, D. J.; Taniuchi, M.; Gratz, J.; Stroup, S. E.; Roberts, J. H.; Kalam, A.; Aziz, F.; Qureshi, S.; Islam, M. O.; Sakpaisal, P.; Silapong, S.; Yori, P. P.; Rajendiran, R.; Benny, B.; McGrath, M.; Seidman, J. C.; Lang, D.; Gottlieb, M.; Guerrant, R. L.; Lima, A. A. M.; Leite, J. P.; Samie, A.; Bessong, P. O.; Page, N.; Bodhidatta, L.; Mason, C.; Shrestha, S.; Kiwelu, I.; Mduma, E. R.; Iqbal, N. T.; Bhutta, Z. A.; Ahmed, T.; Haque, R.; Kang, G.; Kosek, M. N.; Houpt, E. R.; Acosta, A. M.; Rios de Burga, R.; Chavez, C. B.; Flores, J. T.; Olotegui, M. P.; Pinedo, S. R.; Trigoso, D. R.; Vasquez, A. O.; Ahmed, I.; Alam, D.; Ali, A.; Rasheed, M.; Soofi, S.; Turab, A.; Yousafzai, A.; Zaidi, A. K.; Shrestha, B.; Rayamajhi, B. B.; Strand, T.; Ammu, G.; Babji, S.; Bose, A.; George, A. T.; Hariraju, D.; Jennifer, M. S.; John, S.; Kaki, S.; Karunakaran, P.; Koshy, B.; Lazarus, R. P.; Muliyil, J.; Ragasudha, P.; Raghava, M. V.; Raju, S.; Ramachandran, A.; Ramadas, R.; Ramanujam, K.; Rose, A.; Roshan, R.; Sharma, S. L.; Sundaram, S.; Thomas, R. J.; Pan, W. K.; Ambikapathi, R.; Carreon, J. D.; Doan, V.; Hoest, C.; Knobler, S.; Miller, M. A.; Psaki, S.; Rasmussen, Z.; Richard, S. A.; Tountas, K. H.; Svensen, E.; Amour, C.; Bayyo, E.; Mvungi, R.; Pascal, J.; Yarrot, L.; Barrett, L.; Dillingham, R.; Petri, W. A.; Scharf, R.; Ahmed, A. S.; Alam, M. A.; Haque, U.; Hossain, M. I.; Islam, M.; Mahfuz, M.; Mondal, D.; Nahar, B.; Tofail, F.; Chandyo, R. K.; Shrestha, P. S.; Shrestha, R.; Ulak, M.; Bauck, A.; Black, R.; Caulfield, L.; Checkley, W.; Lee, G.; Schulze, K.; Scott, S.; MurrayKolb, L. E.; Ross, A. C.; Schaefer, B.; Simons, S.; Pendergast, L.; Abreu, C. B.; Costa, H.; Di Moura, A.; Filho, J. Q.; Leite, Á. M.; Lima, N. L.; Lima, I. F.; Maciel, B. L.; Medeiros, P. H.; Moraes, M.; Mota, F. 
S.; Oriá, R. B.; Quetz, J.; Soares, A. M.; Mota, R. M.; Patil, C. L.; Mahopo, C.; Maphula, A.; Nyathi, E. Use of Quantitative Molecular Diagnostic Methods to Investigate the Effect of Enteropathogen Infections on Linear Growth in Children in Low-Resource Settings: Longitudinal Analysis of Results from the MAL-ED Cohort Study. Lancet Global Health 2018, 6, e1319-e1328.

(4) Stewart, C. P.; Kariger, P.; Fernald, L.; Pickering, A. J.; Arnold, C. D.; Arnold, B. F.; Hubbard, A. E.; Dentz, H. N.; Lin, A.; Meerkerk, T. J.; Milner, E.; Swarthout, J.; Colford, J. M.; Null, C. Effects of Water Quality, Sanitation, Handwashing, and Nutritional Interventions on Child Development in Rural Kenya (WASH Benefits Kenya): A Cluster-Randomised Controlled Trial. Lancet Child Adolescent Health 2018, 2, 269-280.

(5) Oriá, R. B.; Murray-Kolb, L. E.; Scharf, R. J.; Pendergast, L. L.; Lang, D. R.; Kolling, G. L.; Guerrant, R. L. Early-Life Enteric Infections: Relation between Chronic Systemic Inflammation and Poor Cognition in Children. Nutr. Rev. 2016, 74, 374-386.

(6) Church, J. A.; Parker, E. P.; Kirkpatrick, B. D.; Grassly, N. C.; Prendergast, A. J. Interventions to Improve Oral Vaccine Performance: A Systematic Review and Meta-Analysis. Lancet Infect. Dis. 2019, 19, 203-214.

(7) Luby, S. P.; Rahman, M.; Arnold, B. F.; Unicomb, L.; Ashraf, S.; Winch, P. J.; Stewart, C. P.; Begum, F.; Hussain, F.; Benjamin-Chung, J.; Leontsini, E.; Naser, A. M.; Parvez, S. M.; Hubbard, A. E.; Lin, A.; Nizame, F. A.; Jannat, K.; Ercumen, A.; Ram, P. K.; Das, K. K.; Abedin, J.; Clasen, T. F.; Dewey, K. G.; Fernald, L. C.; Null, C.; Ahmed, T.; Colford, J. M. Effects of Water Quality, Sanitation, Handwashing, and Nutritional Interventions on Diarrhoea and Child Growth in Rural Bangladesh: A Cluster Randomised Controlled Trial. Lancet Global Health 2018, 6, e302-e315.

(8) Null, C.; Stewart, C. P.; Pickering, A. J.; Dentz, H. N.; Arnold, B. F.; Arnold, C. D.; Benjamin-Chung, J.; Clasen, T.; Dewey, K. G.; Fernald, L. C. H.; Hubbard, A. E.; Kariger, P.; Lin, A.; Luby, S. P.; Mertens, A.; Njenga, S. M.; Nyambane, G.; Ram, P. K.; Colford, J. M. Effects of Water Quality, Sanitation, Handwashing, and Nutritional Interventions on Diarrhoea and Child Growth in Rural Kenya: A Cluster-Randomised Controlled Trial. Lancet Global Health 2018, 6, e316-e329.

(9) Humphrey, J. H.; Mbuya, M. N. N.; Ntozini, R.; Moulton, L. H.; Stoltzfus, R. J.; Tavengwa, N. V.; Mutasa, K.; Majo, F.; Mutasa, B.; Mangwadu, G.; Chasokela, C. M.; Chigumira, A.; Chasekwa, B.; Smith, L. E.; Tielsch, J. M.; Jones, A. D.; Manges, A. R.; Maluccio, J. A.; Prendergast, A. J.; Humphrey, J. H.; Jones, A. D.; Manges, A.; Mangwadu, G.; Maluccio, J. A.; Mbuya, M. N. N.; Moulton, L. H.; Ntozini, R.; Prendergast, A. J.; Stoltzfus, R. J.; Tielsch, J. M.; Chasokela, C.; Chigumira, A.; Heylar, W.; Hwena, P.; Kembo, G.; Majo, F. D.; Mutasa, B.; Mutasa, K.; Rambanepasi, P.; Sauramba, V.; Tavengwa, N. V.; Van Der Keilen, F.; Zambezi, C.; Chidhanguro, D.; Chigodora, D.; Chipanga, J. F.; Gerema, G.; Magara, T.; Mandava, M.; Mavhudzi, T.; Mazhanga, C.; Muzaradope, G.; Mwapaura, M. T.; Phiri, S.; Tengende, A.; Banda, C.; Chasekwa, B.; Chidamba, L.; Chidawanyika, T.; Chikwindi, E.; Chingaona, L. K.; Chiorera, C. K.; Dandadzi, A.; Govha, M.; Gumbo, H.; Gwanzura, K. T.; Kasaru, S.; Makasi, R.; Matsika, A. M.; Maunze, D.; Mazarura, E.; Mpofu, E.; Mushonga, J.; Mushore, T. E.; Muzira, T.; Nembaware, N.; Nkiwane, S.; Nyamwino, P.; Rukobo, S. D.; Runodamoto, T.; Seremwe, S.; Simango, P.; Tome, J.; Tsenesa, B.; Amadu, U.; Bangira, B.; Chiveza, D.; Hove, P.; Jombe, H. A.; Kujenga, D.; Madhuyu, L.; Makoni, P. M.; Maramba, N.; Maregere, B.; Marumani, E.; Masakadze, E.; Mazula, P.; Munyanyi, C.; Musanhu, G.; Mushanawani, R. C.; Mutsando, S.; Nazare, F.; Nyarambi, M.; Nzuda, W.; Sigauke, T.; Solomon, M.; Tavengwa, T.; Biri, F.; Chafanza, M.; Chaitezvi, C.; Chauke, T.; Chidzomba, C.; Dadirai, T.; Fundira, C.; Gambiza, A. C.; Godzongere, T.; Kuona, M.; Mafuratidze, T.; Mapurisa, I.; Mashedze, T.; Moyo, N.; Musariri, C.; Mushambadope, M.; Mutsonziwa, T. R.; Muzondo, A.; Mwareka, R.; Nyamupfukudza, J.; Saidi, B.; Sakuhwehwe, T.; Sikalima, G.; Tembe, J.; Chekera, T. E.; Chihombe, O.; Chikombingo, M.; Chirinda, T.; Chivizhe, A.; Hove, R.; Kufa, R.; Machikopa, T. F.; Mandaza, W.; Mandongwe, L.;
Manhiyo, F.; Manyaga, E.; Mapuranga, P.; Matimba, F. S.; Matonhodze, P.; Mhuri, S.; Mike, J.; Ncube, B.; Nderecha, W. T. S.; Noah, M.; Nyamadzawo, C.; Penda, J.; Saidi, A.; Shonhayi, S.; Simon, C.; Tichagwa, M.; Chamakono, R.; Chauke, A.; Gatsi, A. F.; Hwena, B.; Jawi, H.; Kaisa, B.; Kamutanho, S.; Kaswa, T.; Kayeruza, P.; Lunga, J.; Magogo, N.; Manyeruke, D.; Mazani, P.; Mhuriyengwe, F.; Mlambo, F.; Moyo, S.; Mpofu, T.; Mugava, M.; Mukungwa, Y.; Muroyiwa, F.; Mushonga, E.; Nyekete, S.; Rinashe, T.; Sibanda, K.; Chemhuru, M.; Chikunya, J.; Chikwavaire, V. F.; Chikwiriro, C.; Chimusoro, A.; Chinyama, J.; Gwinji, G.; Hoko-Sibanda, N.; Kandawasvika, R.; Madzimure, T.; Maponga, B.; Mapuranga, A.; Marembo, J.; Matsunge, L.; Maunga, S.; Muchekeza, M.; Muti, M.; Nyamana, M.; Azhuda, E.; Bhoroma, U.; Biriyadi, A.; Chafota, E.; Chakwizira, A.; Chamhamiwa, A.; Champion, T.; Chazuza, S.; Chikwira, B.; Chingozho, C.; Chitabwa, A.; Dhurumba, A.; Furidzirai, A.; Gandanga, A.; Gukuta, C.; Macheche, B.; Marihwi, B.; Masike, B.; Mutangandura, E.; Mutodza, B.; Mutsindikwa, A.; Mwale, A.; Ndhlovu, R.; Nduna, N.; Nyamandi, C.; Ruvata, E.; Sithole, B.; Urayai, R.; Vengesa, B.; Zorounye, M.; Bamule, M.; Bande, M.; Chahuruva, K.; Chidumba, L.; Chigove, Z.; Chiguri, K.; Chikuni, S.; Chikwanda, R.; Chimbi, T.; Chingozho, M.; Chinhamo, O.; Chinokuramba, R.; Chinyoka, C.; Chipenzi, X.; Chipute, R.; Chiribhani, G.; Chitsinga, M.; Chiwanga, C.; Chiza, A.; Chombe, F.; Denhere, M.; Dhamba, E.; Dhamba, M.; Dube, J.; Dzimbanhete, F.; Dzingai, G.; Fusira, S.; Gonese, M.; Gota, J.; Gumure, K.; Gwaidza, P.; Gwangwava, M.; Gwara, W.; Gwauya, M.; Gwiba, M.; Hamauswa, J.; Hlasera, S.; Hlukani, E.; Hotera, J.; Jakwa, L.; Jangara, G.; Janyure, M.; Jari, C.; Juru, D.; Kapuma, T.; Konzai, P.; Mabhodha, M.; Maburutse, S.; Macheka, C.; Machigaya, T.; Machingauta, F.; Machokoto, E.; Madhumba, E.; Madziise, L.; Madziva, C.; Madzivire, M.; Mafukise, M.; Maganga, M.; Maganga, S.; Mageja, E.; Mahanya, M.; Mahaso, E.; Mahleka, S.; Makanhiwa, P.; Makarudze, M.; Makeche, C.; Makopa, N.; Makumbe, R.; Mandire, M.; Mandiyanike, E.; Mangena, E.; Mangiro, F.; Mangwadu, A.; Mangwengwe, T.; Manhidza, J.; Manhovo, F.; Manono, I.; Mapako, S.; Mapfumo, E.; Mapfumo, T.; Mapuka, J.; Masama, D.; Masenge, G.; Mashasha, M.; Mashivire, V.; Matunhu, M.; Mavhoro, P.; Mawuka, G.; Mazango, I.; Mazhata, N.; Mazuva, D.; Mazuva, M.; Mbinda, F.; Mborera, J.; Mfiri, U.; Mhandu, F.; Mhike, C.; Mhike, T.; Mhuka, A.; Midzi, J.; Moyo, S.; Mpundu, M.; Msekiwa, N.; Msindo, D.; Mtisi, C.; Muchemwa, G.; Mujere, N.; Mukaro, E.; Muketiwa, K.; Mungoi, S.; Munzava, E.; Muoki, R.; Mupura, H.; Murerwa, E.; Murisi, C.; Muroyiwa, L.; Muruvi, M.; Musemwa, N.; Mushure, C.; Mutero, J.; Mutero, P.; Mutumbu, P.; Mutya, C.; Muzanango, L.; Muzembi, M.; Muzungunye, D.; Mwazha, V.; Ncube, T.; Ndava, T.; Ndlovu, N.; Nehowa, P.; Ngara, D.; Nguruve, L.; Nhigo, P.; Nkiwane, S.; Nyanyai, L.; Nzombe, J.; Office, E.; Paul, B.; Pavari, S.; Ranganai, S.; Ratisai, S.; Rugara, M.; Rusere, P.; Sakala, J.; Sango, P.; Shava, S.; Shekede, M.; Shizha, C.; Sibanda, T.; Tapambwa, N.; Tembo, J.; Tinago, N.; Tinago, V.; Toindepi, T.; Tovigepi, J.; Tuhwe, M.; Tumbo, K.; Zaranyika, T.; Zaru, T.; Zimidzi, K.; Zindo, M.; Zindonda, M.; Zinhumwe, N.; Zishiri, L.; Ziyambi, E.; Zvinowanda, J.; Bepete, E.; Chiwira, C.; Chuma, N.; Fari, A.; Gavi, S.; Gunha, V.; Hakunandava, F.; Huku, C.; Hungwe, G.; Maduke, G.; Manyewe, E.; Mapfumo, T.; Marufu, I.; Mashiri, C.; Mazenge, S.; Mbinda, E.; Mhuri, A.; Muguti, C.; Munemo, L.; Musindo, L.; Ngada, L.; Nyembe, D.; Taruvinga, R.; Tobaiwa, E.; Banda, S.; Chaipa, J.; Chakaza, P.; Chandigere, M.; Changunduma, A.; Chibi, C.; Chidyagwai, O.; Chidza, E.; Chigatse, N.; Chikoto, L.; Chingware, V.; Chinhamo, J.; Chinhoro, M.; Chiripamberi, A.; Chitavati, E.; Chitiga, R.; Chivanga, N.; Chivese, T.; Chizema, F.; Dera, S.; Dhliwayo, A.; Dhononga, P.; Dimingo, E.; Dziyani, M.; Fambi, T.; Gambagamba, L.; Gandiyari, S.; Gomo, C.; Gore, S.; Gundani, J.; Gundani, R.; Gwarima, L.; Gwaringa, C.; Gwenya, S.; Hamilton, R.; Hlabano, A.; Hofisi, E.; Hofisi, F.; Hungwe, S.; Hwacha, S.; Hwara, A.; Jogwe, R.; Kanikani, A.; Kuchicha, L.; Kutsira, M.; Kuziyamisa, K.; Kuziyamisa, M.; Kwangware, B.; Lozani, P.; Mabuto, J.; Mabuto, V.; Mabvurwa, L.; Machacha, R.; Machaya, C.; Madembo, R.; Madya, S.; Madzingira, S.; Mafa, L.; Mafuta, F.; Mafuta, J.; Mahara, A.; Mahonye, S.; Maisva, A.; Makara, A.; Makover, M.; Mambongo, E.; Mambure, 
M.; Mandizvidza, E.; Mangena, G.; Manjengwa, E.; Manomano, J.; Mapfumo, M.; Mapfurire, A.; Maphosa, L.; Mapundo, J.; Mare, D.; Marecha, F.; Marecha, S.; Mashiri, C.; Masiya, M.; Masuku, T.; Masvimbo, P.; Matambo, S.; Matarise, G.; Matinanga, L.; Matizanadzo, J.; Maunganidze, M.; Mawere, B.; Mawire, C.; Mazvanya, Y.; Mbasera, M.; Mbono, M.; Mhakayakora, C.; Mhlanga, N.; Mhosva, B.; Moyo, N.; Moyo, O.; Moyo, R.; Mpakami, C.; Mpedzisi, R.; Mpofu, E.; Mpofu, E.; Mtetwa, M.; Muchakachi, J.; Mudadada, T.; Mudzingwa, K.; Mugwira, M.; Mukarati, T.; Munana, A.; Munazo, J.; Munyeki, O.; Mupfeka, P.; Murangandi, G.; Muranganwa, M.; Murenjekwa, J.; Muringo, N.; Mushaninga, T.; Mutaja, F.; Mutanha, D.; Mutemeri, P.; Mutero, B.; Muteya, E.; Muvembi, S.; Muzenda, T.; Mwenjota, A.; Ncube, S.; Ndabambi, T.; Ndava, N.; Ndlovu, E.; Nene, E.; Ngazimbi, E.; Ngwalati, A.; Nyama, T.; Nzembe, A.; Pabwaungana, E.; Phiri, S.; Pukuta, R.; Rambanapasi, M.; Rera, T.; Samanga, V.; Shirichena, S.; Shoko, C.; Shonhe, M.; Shuro, C.; Sibanda, J.; Sibangani, E.; Sibangani, N.; Sibindi, N.; Sitotombe, M.; Siwawa, P.; Tagwirei, M.; Taruvinga, P.; Tavagwisa, A.; Tete, E.; Tete, Y.; Thandiwe, E.; Tibugari, A.; Timothy, S.; Tongogara, R.; Tshuma, L.; Tsikira, M.; Tumba, C.; Watinaye, R.; Zhiradzango, E.; Zimunya, E.; Zinengwa, L.; Ziupfu, M.; Ziyambe, J.; Church, J. A.; Desai, A.; Fundira, D.; Gough, E.; Kambarami, R. A.; Matare, C. R.; Malaba, T. R.; Mupfudze, T.; Ngure, F.; Smith, L. E.; Curtis, V.; Dickin, K. L.; Habicht, J.-P.; Masimirembwa, C.; Morgan, P.; Pelto, G. H.; SheffnerRogers, C.; Thelingwani, R.; Turner, P.; Zungu, L.; Makadzange, T.; Mujuru, H. A.; Nyachowe, C.; Chakadai, R.; Chanyau, G.; Makamure, M. G.; Chiwariro, H.; Mtetwa, T.; Chikunya, J.; Maguwu, L.; Nyadundu, S.; Moyo, T.; Chayima, B.; Mvindi, L.; Rwenhamo, P.; Muzvarwandoga, S.; Chimukangara, R.; Njovo, H.; Makoni, T. Independent and Combined Effects of Improved Water, Sanitation, and Hygiene, and Improved Complementary Feeding, on Child Stunting and Anaemia in Rural Zimbabwe: A Cluster-Randomised Trial. Lancet Global Health 2019, 7, e132-e147.

(10) Clasen, T.; Boisson, S.; Routray, P.; Torondel, B.; Bell, M.; Cumming, O.; Ensink, J.; Freeman, M.; Jenkins, M.; Odagiri, M.; Ray, S.; Sinha, A.; Suar, M.; Schmidt, W. P. Effectiveness of a Rural Sanitation Programme on Diarrhoea, Soil-Transmitted Helminth Infection, and Child Malnutrition in Odisha, India: A ClusterRandomised Trial. Lancet Global Health 2014, 2, e645-e653.

(11) Patil, S. R.; Arnold, B. F.; Salvatore, A. L.; Briceno, B.; Ganguly, S.; Colford, J. M.; Gertler, P. J. The Effect of India's Total Sanitation Campaign on Defecation Behaviors and Child Health in Rural Madhya Pradesh: A Cluster Randomized Controlled Trial. PLoS Med. 2014, 11, No. e1001709.

(12) Pickering, A. J.; Djebbari, H.; Lopez, C.; Coulibaly, M.; Alzua, M. L. Effect of a Community-Led Sanitation Intervention on Child Diarrhoea and Child Growth in Rural Mali: A Cluster-Randomised Controlled Trial. Lancet Global Health 2015, 3, e701-11.

(13) Bauza, V.; Byrne, D. M.; Trimmer, J. T.; Lardizabal, A.; Atiim, P.; Asigbee, M. A. K.; Guest, J. S. Child Soil Ingestion in Rural Ghana - Frequency, Caregiver Perceptions, Relationship with Household Floor Material and Associations with Child Diarrhoea. Trop. Med. Int. Health 2018, 23, 558-569.

(14) Ngure, F. M.; Humphrey, J. H.; Mbuya, M. N. N.; Majo, F.; Mutasa, K.; Govha, M.; Mazarura, E.; Chasekwa, B.; Prendergast, A. J.; Curtis, V.; Boor, K. J.; Stoltzfus, R. J. Formative Research on Hygiene Behaviors and Geophagy among Infants and Young Children and Implications of Exposure to Fecal Bacteria. Am. J. Trop. Med. Hyg. 2013, 89, 709-716.

(15) Kwong, L. H.; Ercumen, A.; Pickering, A. J.; Unicomb, L.; Davis, J.; Leckie, J. O.; Luby, S. P. Soil Ingestion among Young Children in Rural Bangladesh. J. Exposure Sci. Environ. Epidemiol. 2021, 31, 82-93.

(16) Vermeer, D. E.; Frate, D. A. Geophagia in Rural Mississippi: Environmental and Cultural Contexts and Nutritional Implications. Am. J. Clin. Nutr. 1979, 32, 2129-2135.
(17) Geissler, P. W.; Mwaniki, D. L.; Thiong'o, F.; Friis, H. Geophagy among School Children in Western Kenya. Trop. Med. Int. Health 1997, 2, 624-630.

(18) Parry-jones, B.; Parry-jones, W. L. Pica: Symptom or Eating Disorder? A Historical Assessment. Br. J. Psychiatry 1992, 160, 341354.

(19) Faruque, A. G.; Sack, R. B.; Kosek, M.; George, C. M.; Bhuyian, S. I.; Talukder, K. A.; Lee, G. O.; Perin, J.; Parvin, T.; Azmi, I. J.; Haque, R.; Ahmed, S.; Biswas, S.; Oldja, L.; Mohammad, S. Geophagy Is Associated with Environmental Enteropathy and Stunting in Children in Rural Bangladesh. Am. J. Trop. Med. Hyg. 2015, 92, $1117-1124$

(20) Perin, J.; Thomas, A.; Oldja, L.; Ahmed, S.; Parvin, T.; Bhuyian, S. I.; Sarker, B.; Biswas, S. K.; Faruque, A. S. G.; Sack, R. B.; George, C. M. Geophagy Is Associated with Growth Faltering in Children in Rural Bangladesh. J. Pediatr. 2016, 178, 34-39.e1.

(21) Monira, S.; Bhuyian, M. S. I.; Parvin, T.; Uddin, I. M.; Zohura, F.; Hasan, M. T.; Biswas, S. K.; Hasan, K.; Masud, J.; Rashid, M.; Rahman, Z.; Papri, N.; Rafique, R.; Islam, A.; Barman, I.; Jubyda, F. T.; Johura, F.; Sultana, M.; Sanin, K. I.; Sack, D. A.; Perin, J.; Alam, M.; George, C. M. Child Mouthing of Soil and Presence of Animals in Child Sleeping Spaces Are Associated with Growth Faltering among Young Children in Dhaka, Bangladesh (CHoBI7 Program). Trop. Med. Int. Health 2020, 25, 1016-1023.

(22) Berendes, D. M.; Kirby, A. E.; Clennon, J. A.; Agbemabiese, C.; Ampofo, J. A.; Armah, G. E.; Baker, K. K.; Liu, P.; Reese, H. E.; Robb, K. A.; Wellington, N.; Yakubu, H.; Moe, C. L. Urban Sanitation Coverage and Environmental Fecal Contamination: Links between the Household and Public Environments of Accra, Ghana. PLoS One 2018, 13, No. e0199304.

(23) Baker, K. K.; Senesac, R.; Sewell, D.; Sen Gupta, A.; Cumming, O.; Mumma, J. Fecal Fingerprints of Enteric Pathogen Contamination in Public Environments of Kisumu, Kenya Associated with Human Sanitation Conditions and Domestic Animals. Environ. Sci. Technol. 2018, 52, 10263-10274.

(24) Cairncross, S.; Blumenthal, U.; Kolsky, P.; Moraes, L.; Tayeh, A. The Public and Domestic Domains in the Transmission of Disease. Trop. Med. Int. Health 1996, 1, 27-34.

(25) Holcomb, D. A.; Knee, J.; Sumner, T.; Adriano, Z.; de Bruijn, E.; Nalá, R.; Cumming, O.; Brown, J.; Stewart, J. R. Human Fecal Contamination of Water, Soil, and Surfaces in Households Sharing Poor-Quality Sanitation Facilities in Maputo, Mozambique. Int. J. Hyg. Environ. Health 2020, 226, No. 113496.

(26) Capone, D.; Adriano, Z.; Berendes, D.; Cumming, O.; Dreibelbis, R.; Holcomb, D. A.; Knee, J.; Ross, I.; Brown, J. A Localized Sanitation Status Index as a Proxy for Fecal Contamination in Urban Maputo, Mozambique. PLoS One 2019, 14, No. e0224333.

(27) Bauza, V.; Madadi, V.; Ocharo, R.; Nguyen, T. H.; Guest, J. S. Enteric Pathogens from Water, Hands, Surface, Soil, Drainage Ditch, and Stream Exposure Points in a Low-Income Neighborhood of Nairobi, Kenya. Sci. Total Environ. 2020, 709, No. 135344.

(28) Fuhrmeister, E. R.; Ercumen, A.; Pickering, A. J.; Jeanis, K. M.; Crider, Y.; Ahmed, M.; Brown, S.; Alam, M.; Sen, D.; Islam, S.; Kabir, H.; Islam, M.; Rahman, M.; Kwong, L. H.; Arnold, B. F.; Luby, S. P.; Colford, J. M.; Nelson, K. L. Effect of Sanitation Improvements on Pathogens and Microbial Source Tracking Markers in the Rural Bangladeshi Household Environment. Environ. Sci. Technol. 2020, 54, $4316-4326$.

(29) Navab-Daneshmand, T.; Friedrich, M. N. D.; Gächter, M.; Montealegre, M. C.; Mlambo, L. S.; Nhiwatiwa, T.; Mosler, H.-J.; Julian, T. R. Escherichia Coli Contamination across Multiple Environmental Compartments (Soil, Hands, Drinking Water, and Handwashing Water) in Urban Harare: Correlations and Risk Factors. Am. J. Trop. Med. Hyg. 2018, 98, 803-813.

(30) Kwong, L. H.; Ercumen, A.; Pickering, A. J.; Arsenault, J. E.; Islam, M.; Parvez, S. M.; Unicomb, L.; Rahman, M.; Davis, J.; Luby, S. P. Ingestion of Fecal Bacteria along Multiple Pathways by Young Children in Rural Bangladesh Participating in a Cluster-Randomized 
Trial of Water, Sanitation, and Hygiene Interventions (WASH Benefits). Environ. Sci. Technol. 2020, 54, 13828-13838.

(31) Center for Advancing Microbial Risk Assessment. Quantitative Microbial Risk Assessment (QMRA) Wiki http://qmrawiki.canr.msu. edu (accessed Jan 17, 2019).

(32) Haas, C. N. Quantitative Microbial Risk Assessment (QMRA) and Molecular Biology - Paths to Integration. Environ. Sci. Technol. 2020, 54, 8539-8546.

(33) Bivins, A. W.; Sumner, T.; Kumpel, E.; Howard, G.; Cumming, O.; Ross, I.; Nelson, K.; Brown, J. Estimating Infection Risks and the Global Burden of Diarrheal Disease Attributable to Intermittent Water Supply Using QMRA. Environ. Sci. Technol. 2017, 51, 75427551.

(34) Gerba, C. P.; Rose, J. B.; Haas, C. N.; Crabtree, K. D. Waterborne Rotavirus: A Risk Assessment. Water Res. 1996, 30, 2929-2940.

(35) Brouwer, A. F.; Masters, N. B.; Eisenberg, J. N. S. Quantitative Microbial Risk Assessment and Infectious Disease Transmission Modeling of Waterborne Enteric Pathogens. Curr. Environ. Health Rep. 2018, 5, 293-304.

(36) McBride, G. B.; Stott, R.; Miller, W.; Bambic, D.; Wuertz, S. Discharge-Based QMRA for Estimation of Public Health Risks from Exposure to Stormwater-Borne Pathogens in Recreational Waters in the United States. Water Res. 2013, 47, 5282-5297.

(37) Kundu, A.; McBride, G.; Wuertz, S. Adenovirus-Associated Health Risks for Recreational Activities in a Multi-Use Coastal Watershed Based on Site-Specific Quantitative Microbial Risk Assessment. Water Res. 2013, 47, 6309-6325.

(38) Balderrama-Carmona, A. P.; Gortáres-Moroyoqui, P.; ÁlvarezValencia, L. H.; Castro-Espinoza, L.; Mondaca-Fernández, I.; Balderas-Cortés, J. d. J.; Chaidez-Quiroz, C.; Meza-Montenegro, M. M. Occurrence and Quantitative Microbial Risk Assessment of Cryptosporidium and Giardia in Soil and Air Samples. Int. J. Infect. Dis. 2014, 26, 123-127.

(39) Katukiza, A. Y.; Ronteltap, M.; van der Steen, P.; Foppen, J. W. A.; Lens, P. N. L. Quantification of Microbial Risks to Human Health Caused by Waterborne Viruses and Bacteria in an Urban Slum. J. Appl. Microbiol. 2014, 116, 447-463.

(40) Brown, J.; Cumming, O.; Bartram, J.; Cairncross, S.; Ensink, J.; Holcomb, D.; Knee, J.; Kolsky, P.; Liang, K.; Liang, S.; Nala, R.; Norman, G.; Rheingans, R.; Stewart, J.; Zavale, O.; Zuin, V.; Schmidt, W.-P. A Controlled, before-and-after Trial of an Urban Sanitation Intervention to Reduce Enteric Infections in Children: Research Protocol for the Maputo Sanitation (MapSan) Study, Mozambique. BMJ Open 2015, 5, e008215.

(41) Knee, J.; Sumner, T.; Adriano, Z.; Berendes, D.; de Bruijn, E.; Schmidt, W.-P.; Nalá, R.; Cumming, O.; Brown, J. Risk Factors for Childhood Enteric Infection in Urban Maputo, Mozambique: A Cross-Sectional Study. PLoS Negl. Trop. Dis. 2018, 12, No. e0006956.

(42) Knee, J.; Sumner, T.; Adriano, Z.; Anderson, C.; Capone, D.; Eng, B.; Casmo, V.; Holcomb, D.; Macdougall, A.; Molotkova, E.; Monteiro Braga, J.; Russo, C.; Schmidt, W. P.; Stewart, J.; Zambrana, W.; Zuin, V.; Nalá, R.; Cumming, O.; Brown, J.; et al. Effects of an Urban Sanitation Intervention on Childhood Enteric Infection and Diarrhoea in Mozambique. medRxiv 2020, DOI: 10.1101/ 2020.08.20.20178608.

(43) Capone, D.; Buxton, H.; Cumming, O.; Dreibelbis, R.; Knee, J.; Nalá, R.; Ross, I.; Brown, J. Impact of an Intervention to Improve Pit Latrine Emptying Practices in Low Income Urban Neighborhoods of Maputo, Mozambique. Int. J. Hyg. Environ. Health 2020, 226, 113480.

(44) WaterAid. Spatial Planning for Urban Sanitation and Water I Maputo. 2013.

(45) Boehm, A. B.; Griffith, J.; McGee, C.; Edge, T. A.; SoloGabriele, H. M.; Whitman, R.; Cao, Y.; Getrich, M.; Jay, J. A.; Ferguson, D.; Goodwin, K. D.; Lee, C. M.; Madison, M.; Weisberg, S. B. Faecal Indicator Bacteria Enumeration in Beach Sand: A Comparison Study of Extraction Methods in Medium to Coarse Sands. J. Appl. Microbiol. 2009, 107, 1740-1750.
(46) Rolfe, K. J.; Parmar, S.; Mururi, D.; Wreghitt, T. G.; Jalal, H.; Zhang, H.; Curran, M. D. An Internally Controlled, One-Step, RealTime RT-PCR Assay for Norovirus Detection and Genogrouping. J. Clin. Virol. 2007, 39, 318-321.

(47) Walker, D. I.; McQuillan, J.; Taiwo, M.; Parks, R.; Stenton, C. A.; Morgan, H.; Mowlem, M. C.; Lees, D. N. A Highly Specific Escherichia Coli QPCR and Its Comparison with Existing Methods for Environmental Waters. Water Res. 2017, 126, 101-110.

(48) Lin, W. S.; Cheng, C.-M.; Van, K. T. A Quantitative PCR Assay for Rapid Detection of Shigella Species in Fresh Produce. J. Food Prot. 2010, 73, 221-233.

(49) Baque, R. H.; Gilliam, A. O.; Robles, L. D.; Jakubowski, W.; Slifko, T. R. A Real-Time RT-PCR Method to Detect Viable Giardia Lamblia Cysts in Environmental Waters. Water Res. 2011, 45, 31753184.

(50) Stokdyk, J. P.; Firnstahl, A. D.; Spencer, S. K.; Burch, T. R.; Borchardt, M. A. Determining the $95 \%$ Limit of Detection for Waterborne Pathogen Analyses from Primary Concentration to QPCR. Water Res. 2016, 96, 105-113.

(51) Canales, R. A.; Wilson, A. M.; Pearce-Walker, J. I.; Verhougstraete, M. P.; Reynolds, K. A. Methods for Handling LeftCensored Data in Quantitative Microbial Risk Assessment. Appl. Environ. Microbiol. 2018, 84 (20), No. e01203-18.

(52) Delignette-Muller, M. L.; Dutang, C. Fitdistrplus: An R Package for Fitting Distributions. J. Stat. Software 2015, 64, 1-34.

(53) US EPA. National Center for Environmental Assessment, W. D. Q. and R. M. G. Exposure Factors Handbook Chapter 5 (Update); Soil and Dust Ingestion: Washington, DC, 2017.

(54) Larson, L. R.; Green, G. T.; Cordell, H. K. Children's Time Outdoors: Results and Implications of the National Kids Survey. J. Park Recreation Adm. 2011, 29, 1-20.

(55) Bernander, R.; Palm, J. E. D.; Svärd, S. G. Genome Ploidy in Different Stages of the Giardia Lamblia Life Cycle. Cell. Microbiol. 2001, 3, 55-62.

(56) DuPont, H. L.; Hornick, R. B.; Snyder, M. J.; Libonati, J. P.; Formal, S. B.; Gangarosa, E. J. Immunity in Shigellosis. II. Protection Induced by Oral Live Vaccine or Primary Infection. J. Infect. Dis. 1972, 125, 12-16.

(57) Crockett, C. S.; Haas, C. N.; Fazil, A.; Rose, J. B.; Gerba, C. P. Prevalence of Shigellosis: In the U.S. Consistency with DoseResponse Information. Int. J. Food Microbiol. 1996, 30, 87-99.

(58) Rose, J. B.; Haas, C. N.; Regli, S. Risk Assessment and Control of Waterborne Giardiasis. Am. J. Public Health 1991, 81, 709-713.

(59) Sato, M. I. Z.; Galvani, A. T.; Padula, J. A.; Nardocci, A. C.; de Souza Lauretto, M.; Razzolini, M. T. P.; Hachich, E. M. Assessing the Infection Risk of Giardia and Cryptosporidium in Public Drinking Water Delivered by Surface Water Systems in Sao Paulo State, Brazil. Sci. Total Environ. 2013, 442, 389-396.

(60) Blokker, M.; Smeets, P.; Medema, G. QMRA in the Drinking Water Distribution System. Procedia Eng. 2014, 89, 151-159.

(61) Chaudhry, R.; Hamilton, K.; Haas, C.; Nelson, K. Drivers of Microbial Risk for Direct Potable Reuse and de Facto Reuse Treatment Schemes: The Impacts of Source Water Quality and Blending. Int. J. Environ. Res. Public Health 2017, 14, 635.

(62) Cattaneo, M. D.; Galiani, S.; Gertler, P. J.; Martinez, S.; Titiunik, R. Housing, Health, and Happiness. Am. Econ. J.: Econ. Policy 2009, 1, 75-105.

(63) Pickering, A. J.; Julian, T. R.; Marks, S. J.; Mattioli, M. C.; Boehm, A. B.; Schwab, K. J.; Davis, J. Fecal Contamination and Diarrheal Pathogens on Surfaces and in Soils among Tanzanian Households with and without Improved Sanitation. Environ. Sci. Technol. 2012, 46, 5736-5743.

(64) Ercumen, A.; Pickering, A. J.; Kwong, L. H.; Mertens, A.; Arnold, B. F.; Benjamin-Chung, J.; Hubbard, A. E.; Alam, M.; Sen, D.; Islam, S.; Rahman, M. Z.; Kullmann, C.; Chase, C.; Ahmed, R.; Parvez, S. M.; Unicomb, L.; Rahman, M.; Ram, P. K.; Clasen, T.; Luby, S. P.; Colford, J. M. Do Sanitation Improvements Reduce Fecal Contamination of Water, Hands, Food, Soil, and Flies? Evidence from 
a Cluster-Randomized Controlled Trial in Rural Bangladesh. Environ. Sci. Technol. 2018, 52, 12089-12097.

(65) Dingle, T. C.; Sedlak, R. H.; Cook, L.; Jerome, K. R. Tolerance of Droplet-Digital PCR vs Real-Time Quantitative PCR to Inhibitory Substances. Clin. Chem. 2013, 59, 1670-1672.

(66) Fuhrmeister, E. R.; Ercumen, A.; Pickering, A. J.; Jeanis, K. M.; Ahmed, M.; Brown, S.; Arnold, B. F.; Hubbard, A. E.; Alam, M.; Sen, D.; Islam, S.; Kabir, M. H.; Kwong, L. H.; Islam, M.; Unicomb, L.; Rahman, M.; Boehm, A. B.; Luby, S. P.; Colford, J. M.; Nelson, K. L. Predictors of Enteric Pathogens in the Domestic Environment from Human and Animal Sources in Rural Bangladesh. Environ. Sci. Technol. 2019, 53, 10023-10033.

(67) Olson, M. E.; Goh, J.; Phillips, M.; Guselle, N.; McAllister, T. A. Giardia Cyst and Cryptosporidium Oocyst Survival in Water, Soil, and Cattle Feces. J. Environ. Qual. 1999, 28, 1991.

(68) Yeager, J. G.; Ward, R. L. Effects of Moisture Content on LongTerm Survival and Regrowth of Bacteria in Wastewater Sludge. Appl. Environ. Microbiol. 1981, 41, 1117-1122.

(69) Montealegre, M. C.; Roy, S.; Böni, F.; Hossain, M. I.; NavabDaneshmand, T.; Caduff, L.; Faruque, A. S. G.; Islam, M. A.; Julian, T. R. Risk Factors for Detection, Survival, and Growth of AntibioticResistant and Pathogenic Escherichia Coli in Household Soils in Rural Bangladesh. Appl. Environ. Microbiol. 2018, 84 (24), No. e01978-18.

(70) Hijnen, W. A. M.; Beerendonk, E. F.; Medema, G. J. Inactivation Credit of UV Radiation for Viruses, Bacteria and Protozoan (Oo)Cysts in Water: A Review. Water Res. 2006, 40, 3-22.

(71) Covacin, C.; Aucoin, D. P.; Elliot, A.; Thompson, R. C. A. Genotypic Characterisation of Giardia from Domestic Dogs in the USA. Vet. Parasitol. 2011, 177, 28-32.

(72) Heyworth, M. F. Giardia Duodenalis Genetic Assemblages and Hosts. Parasite 2016, 23, No. 13.

(73) Castel-Branco, K. R. Legislating Worker Justice: The Formalisation of Paid Domestic Work in Maputo, Mozambique; University of KwaZulu-Natal: Durban, 2012.

(74) Penakalapati, G.; Swarthout, J.; Delahoy, M. J.; McAliley, L.; Wodnik, B.; Levy, K.; Freeman, M. C. Exposure to Animal Feces and Human Health: A Systematic Review and Proposed Research Priorities. Environ. Sci. Technol. 2017, 51, 11537-11552.

(75) Berendes, D. M.; Yang, P. J.; Lai, A.; Hu, D.; Brown, J. Estimation of Global Recoverable Human and Animal Faecal Biomass. Nat. Sustainability 2018, 1, 679-685.

(76) Kotloff, K. L.; Riddle, M. S.; Platts-Mills, J. A.; Pavlinac, P.; Zaidi, A. K. M. Shigellosis. Lancet 2018, 391, 801-812.

(77) Zehra, D.; Mbatha, S.; Campos, L. C.; Queface, A.; Beleza, A.; Cavoli, C.; Achuthan, K.; Parikh, P. Rapid Flood Risk Assessment of Informal Urban Settlements in Maputo, Mozambique: The Case of Maxaquene A. Int. J. Disaster Risk Reduct. 2019, 40, 101270. DOI: $10.1016 /$ j.ijdrr.2019.101270.

(78) Schwartz, B. S.; Harris, J. B.; Khan, A. I.; LaRocque, R. C.; Sack, D. A.; Malek, M. A.; Faruque, A. S. G.; Qadri, F.; Calderwood, S. B.; Luby, S. P.; Ryan, E. T. Diarrheal Epidemics in Dhaka, Bangladesh, during Three Consecutive Floods: 1988, 1998, and 2004. Am. J. Trop. Med. Hyg. 2006, 74, 1067-1073.

(79) Sclar, G. D.; Penakalapati, G.; Amato, H. K.; Garn, J. V.; Alexander, K.; Freeman, M. C.; Boisson, S.; Medlicott, K. O.; Clasen, T. Assessing the Impact of Sanitation on Indicators of Fecal Exposure along Principal Transmission Pathways: A Systematic Review. Int. J. Hyg. Environ. Health 2016, 219, 709-723.

(80) Rollins, D. M.; Colwell, R. R. Viable but Nonculturable Stage of Campylobacter Jejuni and Its Role in Survival in the Natural Aquatic Environment Downloaded From. Appl. Environ. Microbiol. 1986, 52, 531-538.

(81) Nielsen, K. M.; Johnsen, P. J.; Bensasson, D.; Daffonchio, D. Release and Persistence of Extracellular DNA in the Environment. Environ. Biosafety Res. 2007, 6, 37-53.

(82) Elizaquível, P.; Aznar, R.; Sánchez, G. Recent Developments in the Use of Viability Dyes and Quantitative PCR in the Food Microbiology Field. J. Appl. Microbiol. 2014, 116, 1-13.
(83) Fu, Y.; Ye, Z.; Jia, Y.; Fan, J.; Hashmi, M. Z.; Shen, C. An Optimized Method to Assess Viable Escherichia Coli O157:H7 in Agricultural Soil Using Combined Propidium Monoazide Staining and Quantitative PCR. Front. Microbiol. 2020, 11, 1809.

(84) Haas, C. N. Microbial Dose Response Modeling: Past, Present, and Future. Environ. Sci. Technol. 2015, 49, 1245-1259.

(85) Bartelt, L. A.; Platts-Mills, J. A. Giardia: A Pathogen or Commensal for Children in High-Prevalence Settings? Current Opinion in Infectious Diseases 2016, 29, 502-507.

(86) Glynn, J. R.; Bradley, D. J. The Relationship between Infecting Dose and Severity of Disease in Reported Outbreaks of Salmonella Infections. Epidemiol. Infect. 1992, 109, 371-388.

(87) Raman, A. S.; Gehrig, J. L.; Venkatesh, S.; Chang, H.-W.; Hibberd, M. C.; Subramanian, S.; Kang, G.; Bessong, P. O.; Lima, A. A. M.; Kosek, M. N.; Petri, W. A.; Rodionov, D. A.; Arzamasov, A. A.; Leyn, S. A.; Osterman, A. L.; Huq, S.; Mostafa, I.; Islam, M.; Mahfuz, M.; Haque, R.; Ahmed, T.; Barratt, M. J.; Gordon, J. I. A Sparse Covarying Unit That Describes Healthy and Impaired Human Gut Microbiota Development. Science 2019, 365, No. eaau4735.

(88) Rendtorff, R. C. The Experimental Transmission of Human Intestinal Protozoan Parasites. Am. J. Epidemiol. 1954, 59, 209-222.

(89) Byappanahalli, M. N.; Yan, T.; Hamilton, M. J.; Ishii, S.; Fujioka, R. S.; Whitman, R. L.; Sadowsky, M. J. The Population Structure of Escherichia Coli Isolated from Subtropical and Temperate Soils. Sci. Total Environ. 2012, 417-418, 273-279.

(90) Ishii, S.; Ksoll, W. B.; Hicks, R. E.; Sadowsky, M. J. Presence and Growth of Naturalized Escherichia Coli in Temperate Soils from Lake Superior Watersheds. Appl. Environ. Microbiol. 2006, 72, 612621 .

(91) Leonardopoulos, J.; Papakonstantinou, A.; Kourti, H.; Papavassiliou, J. Survival of Shigellae in Soil. Zentralbl. Bakteriol. Mikrobiol. Hyg. B 1980, 171, 459-465.

(92) Rose, J.; Jiménez-Cisneros, B.; Murphy, H. Persistence of Pathogens in Sewage and Other Water Types. In Global Water Pathogen Project; Michigan State University, 2019.

(93) Aw, T. Environmental Aspects and Features of Critical Pathogen Groups. In Global Water Pathogen Project; Michigan State University, 2019. 